\title{
1. A step too far? Constitutional objections to harmonisation of EU consumer and contract law
}

\author{
Adam Cygan
}

\section{INTRODUCTION}

The financial crisis and increasing unemployment have all necessitated that the EU adopts innovative policies to stimulate economic growth. Within the EU it remains the internal market which is at the core of EU trade policy and the Commission has been looking at ways in which to increase the volume of trade between Member States, especially by encouraging new opportunities for individual consumers. As part of the Europe 2020 Programme the Commission has been promoting its 'Digital Agenda' ${ }^{1}$ through which the Commission, amongst other initiatives, seeks to improve online sales and e-commerce of cross-border goods and services by consumers. ${ }^{2}$ In addition to the necessary technological developments, the Commission concludes that this can only be realised through the adoption of a uniform legal framework and effective consumer protection measures which will instil in consumers the confidence and protection that is necessary to guard against fraud and protect consumer rights.

The Commission Communication Towards a Single Market Act ${ }^{3}$ and the Digital Agenda ${ }^{4}$ both highlight that significant fragmentation of online markets in Europe prevents growth and prevents consumers from obtaining the full benefit of the single market. Therefore, as part of the Agenda 2020 strategy through which the EU seeks to meet the goals of higher growth, employment and social cohesion, increasing the volume of online trade may, superficially, be considered as a logical component

$\operatorname{COM}(2010) 245$ final.

2 As part of the Digital Agenda the EU has set itself the target of raising the proportion of consumers who shop online across borders to $20 \%$ by 2020 .

$3 \operatorname{COM}(2010) 608$ final.

$4 \operatorname{COM}(2010) 245$ final at p. 5. 
of the strategy. Given that consumer expenditure accounts for approximately 56 per cent of EU GDP 5 it is understandable that the EU wants to harness this economic activity and use it to drive economic growth.

Yet the EU's e-commerce strategy, where the focus lies on increasing cross-border commerce, is not without criticism and raises a number of constitutional and institutional questions which challenge the presumptions put forward by the Commission of the necessity for the proposed Regulation for Common European Sales Law for the European Union (CESL). ${ }^{6}$ In this context, the primary issues addressed by this chapter are whether the EU's policy and legislative agenda, which seeks to harmonise EU consumer sales legislation through the creation of a twenty-ninth contract law regime, ${ }^{7}$ is necessary to the improved functioning of internal market trade and especially e-commerce. Moreover, will the proposed CESL Regulation provide new opportunities and value-added rights for EU citizens engaging in online transactions which individual Member States cannot efficiently deliver acting independently?

To this extent, the chapter examines the constitutional implications of EU harmonisation of consumer protection and contract rules. In particular, this chapter explores the application of the relevance of the constitutional principle of subsidiarity and questions whether EU harmonisation offers clear value-added benefits for consumers. The analysis in this chapter focuses upon the proposed CESL Regulation, ${ }^{8}$ as an example of an EU attempt to harmonise certain contractual rules, and whether the proposal meets the legislative justifications laid out in Article 5 TEU and Protocol 2 of the Treaty. ${ }^{9}$ The discussion will also analyse the constitutional question of the choice of legal base for the proposed CESL Regulation and whether, in the light of the complementary and optional nature of the proposed Regulation, Article 114 TFEU provides the most appropriate procedure through which to implement a Regulation which will operate alongside existing domestic contractual law. Finally, the

$5 \operatorname{COM}(2010) 608$ final at p. 3.

$6 \operatorname{COM}(2011) 635$ final Draft Regulation on a Common European Sales Law for the European Union.

7 The original proposal referred to the creation of a 'twenty-eighth' regime but with the accession of Croatia to the EU in July 2012 it is now appropriate to refer to this alternative set of contract rules as the 'twenty-ninth regime'.

8 Although the proposal for CESL was withdrawn in December 2014, the discussion in this chapter remains relevant for the expected revised proposal which is likely to be put forward in the context of the new Digital Single Market Strategy (2015) 192 final.

9 Protocol 2 on the Application of the Principle of Subsidiarity and Proportionality OJ 2008 C115. 
chapter argues that the example of the CESL demonstrates that from a constitutional perspective EU harmonisation in the field of contract and consumer law has not been adequately justified because it fails to satisfy the 'test' for EU legislative action included within Article 5 TEU, namely that Member States acting independently are unable to achieve the same objective.

\section{THE PROPOSAL FOR THE CESL REGULATION}

The core of the Commission's proposals for the CESL Regulation is a set of uniform contract law rules which parties to a contract could choose to opt into to cover their contractual relationship when they are engaging in cross-border e-commerce trade. Thus, the contractual provisions, which must be viewed as being purely voluntary and having no mandatory legal force, do not create any positive obligation on the contracting parties that they will become the choice of law. ${ }^{10}$ The Regulation, on which there is a clear lack of political consensus ${ }^{11}$ would form part of the national law of each Member State and provide an alternative regime from those currently offered by existing domestic contract laws. The alternative, or so-called twenty-ninth, regime would be available to consumers in circumstances of cross-border business-to-consumer contracts or business-to-business contracts where at least one of the businesses is a Small/Medium Enterprise (SME).

In the Explanatory Memorandum which accompanied the proposed CESL Regulation the Commission justified the proposal in the following terms: ${ }^{12}$

Differences in contract law between Member States hinder traders and consumers who want to engage in cross-border trade within the internal market. The obstacles which stem from these differences dissuade traders, small and medium-sized enterprises (SME) in particular, from entering cross

10 See $\operatorname{COM}(2001) 398$ final, Communication from the Commission to the Council and the European Parliament at p. 5.

11 See EA Posner 'The questionable basis of the common European sales law: The role of an optional instrument in jurisdictional competition' (2013) 50 Common Market Law Review, 261-76 at 262.

$12 \operatorname{COM}(2011) 636$ final, Communication from the Commission to the European Parliament, the Council and the Economic and Social Committee and the Committee of the Regions on a Common European Sales Law to facilitate cross-border transactions in the Single Market. 
border trade or expanding to new Member States' markets. Consumers are hindered from accessing products offered by traders in other Member States.

The Commission's explanation and justification of the need for some form of positive integration is primarily based upon the existence of practical and legal barriers which inhibit cross-border e-commerce activity. The Commission justification that variations in contract law between the Member States 'hinder' trade are based upon surveys which, for example, show that of the range of obstacles to cross-border trade including tax regulations, administrative requirements, difficulties in delivery, language and culture, traders ranked contract-law-related obstacles among the primary barriers to cross-border trade. ${ }^{13}$ This justification for what essentially constitutes a legal problem is primarily economic in its nature, ${ }^{14}$ and validates harmonisation because it will, in the Commission's view, lead to tangible benefits for EU citizens. ${ }^{15}$ This reasoning is aimed not only at sceptical traders and consumers who remain wary of engaging in cross-border e-commerce, but also simultaneously seeks to satisfy the subsidiarity requirement within Article 5 TEU that an EU legislative proposal is both necessary and that it would offer a valueadded solution to the existing regulatory regime which Member States acting independently could not achieve through their own national legislation.

The CESL Regulation may be considered as an attempt at the 'Europeanisation' of contract law, but unlike other internal market measures which seek to harmonise and replace the laws of Member States, this Regulation would provide an additional and, crucially, optional contract law regime that is common to all Member States and which would co-exist alongside national contract law. This dualist

13 See $\operatorname{COM}(2011) 636$ final at p. 2, Eurobarometer 320 on European contract law in business-to-business transactions of 2011, p. 15 and Eurobarometer 321 on European contract law in consumer transactions of 2011, p. 19.

14 The Commission identifies that traders who are dissuaded from crossborder transactions to contract law obstacles forgo at least €26 billion in intra-EU trade each year. This estimate is based upon business responses to the SME Panel Survey on the Impacts of European contract law, available 5 April 2016 at http://ec.europa.eu/justice/contract/files/report_sme_panel_survey_en.pdf.

15 The benefit to the consumer is the primary justification which the Commission has consistently put forward in its policy documents. See further COM(2003) 68 final, A More Coherent European Contract Law - An Action Plan and $\operatorname{COM(2010)~} 348$ final Green Paper from the Commission on Policy Options for Progress for a European Contract Law for Consumers and Businesses. 
approach may appear ostensibly as a 'best of both worlds' solution by giving parties another option, but by making the European Sales Law optional the justifications of necessity and valued-added action by the EU are severely undermined and call into question the Commission's view that the proposal satisfies the principle of subsidiarity.

If selected, the optional contract law would govern the parties' relationship to the exclusion of any other law in relation to all matters governed by the optional contract. ${ }^{16}$ Both parties would first need to agree to use the optional law and in a formal contractual context, it would appear to be the vendor who would choose which law to offer and the other party would need to formally consent to its use. In circumstances where no agreement were to be explicitly established in this manner, the parties' contractual relationship would be governed by whichever law was indicated by the provisions of the Regulation 593/ 2008 on the law applicable to contractual obligations (The Rome I Regulation). ${ }^{17}$ This analysis presumes an equality of bargaining power between the parties who will voluntarily agree to use the CESL. However, in reality this is questionable because purchasers could be faced with an option of either agreeing to opt into the CESL or not being able to complete the transaction.

Substantively, the optional nature of the proposal is its very weakness and is likely to undermine its efficacy should the proposal become law. ${ }^{18}$ Practically, it is difficult to justify why contracting parties would choose to opt in. The 'virtual' nature of the twenty-ninth regime would arguably raise negative connotations in the eyes of both contracting parties who would be opting in to a contractual regime that is not specifically linked to the judicial system of a Member State. Moreover, it is the optional nature of the proposal which raises questions concerning the legality of the proposal and whether the proposal has been introduced under the correct legal base.

16 It should be noted that a number of matters which might arise in a contractual relationship are not governed by the European Sales Law and are listed in Recital (27) of the Regulation.

17 Regulation (EC) No. 593/2008 of the European Parliament and of the Council of 17 June 2008 on the law applicable to contractual relations (Rome I) OJ 2008 L177.

18 See further, JJ Ganuza and F Gomez 'Optional law for firms and consumers: An economic analysis of opting into a common European sales law' (2013) 50 Common Market Law Review 29-50. 


\section{THE CHOICE OF LEGAL BASE - THE CASE AGAINST ARTICLE 114 TFEU}

\section{(a) The Scope of Article 114 TFEU}

Legal base is important because it provides the EU with the competence to introduce harmonising legislation in a given policy area and determines the legislative process that will be used. Under Article 5 TEU, the principle of conferral limits EU legislative action to only those policy areas mentioned within the Treaty. While sectoral Treaty bases have become more common since the Single European Act 1986, much harmonising legislation is still based upon the general legal base of Article 114 TFEU which is used to regulate the internal market. For all internal market measures falling under Article 114 TFEU this means that qualified majority voting is used by the Council and the ordinary legislative procedure under Article 289 TFEU will apply.

Article 114 TFEU (or it predecessor Article 95 EC) does not vest the EU legislator with 'a general power to regulate the Internal Market'. ${ }^{19}$ In Case 436/03P Parliament $v$ Council the Court held that any measures based upon Article 114 TFEU must actually and genuinely contribute (emphasis added) to eliminating obstacles to trade and removing distortions of competition. This seemingly places a boundary upon the unlimited exercise of EU competence and jurisdiction and the subsidiarity principle in Article 5 TEU is a core component of this restriction. ${ }^{20}$ In the context of the proposal for the CESL, the optional nature strongly suggests that it is not a harmonisation measure in the strict sense, raising questions as to whether Article 114 TFEU is the appropriate legal base. This is primarily because the Regulation will not replace existing national contractual laws with a single new legislative framework, which in turn adds weight to the proposition that this proposal does not help to eliminate obstacles to the efficient functioning of the internal market. It may be argued that if the measure was so effective and necessary to eliminate obstacles then it would be compulsory for all cross-border online transactions.

19 Case C-376/98 Germany v European Parliament and Council (Tobacco Advertising) [2000] ECR I-8419 at para.83.

20 Case C-436/03P European Parliament and Commission v Council [2006] ECR I-1025. 
According to Article 114(1) TFEU the EU may adopt 'measures for the approximation of provisions laid down by law, regulation or administrative action in Member States which have as their objective the establishment and functioning of the Internal Market'. On a strict interpretation of Article 114(1) TFEU it may be argued that the optional nature precludes its use as the legal base because the requirement of 'approximation' of the laws of Member States should be interpreted as precisely that. Specifically, approximation is the culmination of a supranational legislative process which leads to the adoption of a single legislative and governance framework that replaces existing domestic provisions. The elective nature of the CESL, whereby it sits alongside existing national laws for parties to choose should not be considered as harmonisation, primarily because while there may be a judicial sanction levied against Member States for not implementing the Regulation, there can be no sanction available in circumstances where Member States do not promote its use over national contract law.

The process of legislative harmonisation which the EU has embarked upon since the Single European Act 1986 operates in such a manner that the laws of Member States are approximated to a minimum standard. The defining feature of this approximation is that EU legislation replaces all other existing national laws and is uniformly interpreted by both the European Court of Justice and national courts. The CESL Regulation would create identical legislation within all the Member States, to the extent that the contractual parties will have the choice of opting into it, but this is neither substantially nor constitutionally akin to this being the only legislative option available. Substantially, though Member States will not be able to maintain or introduce domestic legislation which prevents contracting parties choosing the CESL to govern their contractual relationship, there is nothing within the Regulation that they must positively promote its use. Perhaps more significant are the constitutional limitations of the Regulation in its current optional form. From a constitutional perspective and looking through the prism of the principle of supremacy, which the Court has espoused from its first judgment in van Gend en $\operatorname{Loos}^{21}$ and upon which the foundations of the internal market rest, it is very difficult to conclude that a Regulation which contains provisions that do not bind Member States with regard to their operative effect could be considered equivalent to legislative provisions which introduce a binding regulatory norm across all Member States.

21 Case 26/62 Van Gend en Loos v Nederlandse Administratie der Belastingen [1963] ECR 1. 


\section{(b) Article 352 TFEU}

The case against the use of Article 114 TFEU is further strengthened by the examples of previous occasions where the EU has adopted measures which have similarly created optional legal regimes. For example, in Case 436/03P Parliament $v$ Council, the Court held that a Regulation creating a European form of Co-operative Society, ${ }^{22}$ which was to co-exist alongside existing national rules that regulated co-operative societies, was correctly adopted on the basis of the residual power that is now found in Article 352 TFEU. Crucially the Court concluded that this Regulation could not have been adopted under Article 114 TFEU. In its judgment, the Court found that the Regulation for the creation of a European Co-operative Society was a new legal form which would exist alongside co-operative societies that had been formed under national law. As the Court pointed out ${ }^{23}$ the legislation has its own specific characteristics and left some subsidiary matters to be governed by national law. Crucially, these subsidiary matters were not harmonised by the Regulation and in the circumstances of CESL, a similar observation may be made, for example, in relation to the rules governing the legal capacity to enter into a contract or what constitutes a representation under the contract. Moreover, the title of the Regulation spells out its aim; namely the creation of a 'common' law to govern cross-border contracts which the Regulation explicitly states will co-exist alongside existing national laws. ${ }^{24}$ From a proportionality perspective as set out in Article 5 TEU the Regulation should not go beyond this and thus the legislation should only have the purpose of increasing choice for parties when creating legal relationships and not of prescribing a single uniform contractual regime. $^{25}$

On this interpretation the Regulation can be considered as an autonomous and self-contained legislative proposal which will be applied only in those circumstances where the contracting parties choose it as the regulatory medium. There is no scope for overlap, or resort to legal principles in national law when the CESL is the choice of law and vice

\footnotetext{
22 C-436/03 European Parliament v Council [2006] ECR I-3733.

23 At paras 43-44.

24 The European Commission's Explanatory Memorandum states in section 3 that 'The Common European Sales Law will be an optional regime in addition to pre-existing contract rules without replacing them'.

25 Recitals (6) and (8) and Article 1 of Preamble of the Regulation refer to the CESL as a 'single uniform set of rules across the Member States'.
} 
versa. ${ }^{26}$ The autonomous nature of the legislation is reinforced by Article 11 which provides that "where the parties have validly agreed to use the CESL for a contract, only the CESL shall govern the matters addressed in its rules'. This ring-fencing nature of the CESL and its effects could not be clearer and these are different in both form and effect from a strict harmonising measure, adding further weight to the argument against Article 114 TFEU being the appropriate Treaty base. Furthermore, under Article 114 TFEU the legislative process requires qualified majority voting in the Council. At its core, the rationale for qualified majority voting is an imperative for approximation of laws where it is recognised within the political and legislative process that the legislation is necessary to bring down barriers to free movement. It seems difficult to justify the use of a legislative procedure which has a presumptive imperative of the need to reach agreement for a Regulation, but which will not create a mandatory obligation.

In its present form the proposed Regulation can be considered as a schizophrenic document. The Commission states in the accompanying Explanatory Memorandum that the contractual rules will be optional through the creation of a twenty-ninth regime. This seemingly complies with the principle of proportionality, yet the Preamble to the Regulation states that it:

... harmonises the contract laws of the Member States not by requiring amendments to the pre-existing national contract law, but by creating within each Member State's national law a second contract law regime for contracts within its scope.

The use of the term 'harmonisation' is both misleading and potentially infringes the principle of proportionality. ${ }^{27}$ A legislative measure which in the Commission's own Explanatory Memorandum stresses the supplementary nature of the proposal cannot become a fully-fledged measure that approximates national laws within the meaning of Article 114 TFEU simply by virtue of such a statement included within the Preamble. For the reasons discussed above the proposed CESL cannot and should not be viewed as a measure which approximates national laws. The reference to

26 Recital (29) states that the 'Common European Sales Law should be interpreted autonomously in accordance with well-established principles on the interpretation of Union law. Questions concerning the matters falling within the scope of the Common European Sales Law which are not expressly settled by it should be resolved only by interpretation of its rules without recourse to any other law'.

27 See also Posner (2013) (n.11) at 263-4. 
'harmonisation' within the Preamble may be construed as an attempt by the Commission to circumvent the effects of the judgment in Case 436/03P Parliament v Council where the Court considered such legislative measures which propose co-existing legal regimes as creating 'a new legal form' and which therefore seeks to reject the analysis that such legislation constitutes harmonisation. The proposed Regulation could, hypothetically, have no regulatory effect on national law or affect the way in which parties conduct their contractual affairs. Indeed, it is practically very difficult to see why any consumer would wish to opt into what in many ways is a 'virtual' legal regime.

In one chief respect the discussion about Treaty base is somewhat anodyne. As will become apparent from the discussion in forthcoming sections, the proposed Regulation raises serious questions of its compatibility with the principle of subsidiarity and whether the EU should be seeking to regulate contract law in any form, optional or otherwise. However, the discussion of Treaty base would not be complete without examining whether any alternatives to Article 114 TFEU exist as a legal base for the Regulation. Given the optional nature of the Regulation and the judgment of the Court in Case 436/03P Parliament $v$ Council, both of which should preclude the use of Article 114 TFEU as the legal base, then would Article 352 TFEU provide an alternative legal base?

In its current form the proposal is much closer to the sort of measure which would be better introduced under Article 352 TFEU. Support for the use of Article 352 TFEU comes not just from the judgment in Case 436/03P Parliament $v$ Council, but also from the use of this Treaty base for the Regulation for a Statute for a European Company (SE). ${ }^{28}$ Article 352 TFEU enables the EU to agree legislation which, inter alia, cannot be introduced under Article 114 TFEU, but where such legislation falls 'within the framework of policies defined in the Treaty, to attain one of the objectives set out in the Treaties, and the Treaties have not provided the necessary powers'. The Treaty provides no legal base for the introduction of optional contractual legal rules, but Article 352 TFEU has been used as legal base for optional legal constructs.

The absence of specific Treaty powers itself signals a prima facie argument against the need for integration, and while it is accepted that not every legislative act can be anticipated by the Treaty, the inclusion of

28 Council Regulation (EC) No 2157/2001 of 8 October 2001 on the Statute for a European Company. OJ 2001 L294/1. The Treaty base used was the previous version found in Article 308 EC. Though broader in scope the general powers and legislative procedures used for legislation agreed under these two Treaty provisions are similar. 
Article 352 TFEU impliedly indicates that the Treaty distinguishes between legislation which is necessary to the functioning of the internal market and that which may be required should circumstances require EU action. This is further confirmed by the use of unanimity for decisionmaking under Article 352 TFEU with the European Parliament being consulted, indicating that a high threshold of necessity and justification needs to be satisfied which goes beyond that required in circumstances of the existence of a specific Treaty base. Article 352 TFEU therefore enables the EU to 'plug' a legal vacuum, rather than providing a default alternative Treaty base in the absence of a specific one, but it remains doubtful whether the Commission has even justified the use of Article 352 TFEU and provided sufficient evidence that the introduction of an optional contractual law will improve the functioning of the internal market and that harmonisation of contract law, optional or otherwise, can be considered as an objective under the Treaty.

\section{(c) Cooperation on Matters of Civil Procedure}

The Treaty provides a specific legal base under which the EU is granted the legislative power to harmonise civil law. There is no doubt that contract law comes firmly within the scope of domestic civil law and Article 81 TFEU enables the EU 'to develop civil matters having crossborder implications particularly where necessary for the proper functioning of the Internal Market'. Ostensibly, Article 81 TFEU could, on a broad interpretation, be considered as a legal base, but as has already been argued in the context of Article 114 TFEU, it is questionable whether harmonisation is necessary for the proper functioning of the internal market. Although EU action based upon Article 81 TFEU may include approximation measures, all of the examples listed in Article 81(2) TFEU concern procedural law and do not identify circumstances such as those of the proposed Regulation for a CESL whose purpose is to create a new supplementary set of substantive contract law rules.

Given the procedural nature and focus of Article 81 TFEU, the omission within Article 81 TFEU to specifically mention the need for any form of harmonisation for contract law would appear to rule it out as a legal base. Article 81 TFEU is essentially concerned with cross-border judicial cooperation and mutual recognition of judgments and relevant conflicts of laws rules and its use is likely to remain within the realms of family law and enforcing civil judgments. 


\section{IMPACT ASSESSMENT AND SUBSIDIARITY CONSIDERATIONS OF THE CESL}

The need for EU legislative action under Article 114 TFEU arises from a justification that without legislative approximation the internal market would not function efficiently. The maintenance of regulatory differences between the Member States would lead to the continuation of barriers towards further integration which would be to the detriment of the citizen. This is an objective conclusion and one which requires independent evidential corroboration. The key part of the legislative process in which the Commission seeks to provide the justification that Article 114 TFEU should provide the legal base comes at the stage of the Impact Assessment. In this Impact Assessment the Commission must provide a justification for why EU action is required and why the same result cannot be achieved by the Member States acting independently. In the case of the latter, this requirement addresses the obligation under Article 5 TEU that legislation is compliant with the principle of subsidiarity. ${ }^{29}$

Since 2001 the Commission has been pursuing what is known as the 'Better Regulation Agenda' at the core of which is the use of 'impact assessments'. Under the process of better regulation the Commission's 'aim of smart regulation is to design and deliver regulation that respects the principles of subsidiarity and proportionality and is of the highest quality possible. This must be done throughout the policy cycle from the moment the legislation is designed to when it is revised and then implemented.' 30

What may be taken from this is that the core requirement of better regulation is a thorough impact assessment of the legislative proposal produced by the Commission. ${ }^{31}$ This is particularly important because if subsidiarity monitoring is to be conducted by national parliaments under

29 See S Weatherill 'Competence and legitimacy' in C Barnard and O Oduhu (eds) The Outer Limits of European Union Law (Hart Publishing, 2009) 17 and A Cygan 'The parliamentarisation of EU decision-making? The impact of the Treaty of Lisbon on national parliaments' (2011) 36 European Law Review 478-99 at 484-5.

30 See COM(2010) 543 final, Smart Regulation in the European Union at p. 3 .

31 See COM(2005) 97 final, Better Regulation for Growth and Jobs in the European Union at pp. 4-5 where the Commission highlights that better regulation cannot be achieved without meeting the principle of subsidiarity and that the Commission has an obligation within impact assessments to ensure that the principle is adhered to. 
the procedures of Protocol 2, then they must all work from the same documentation in order to measure whether the proposal infringes the principle of subsidiarity. While this does not guarantee equal results across the national parliaments primarily because of different internal parliamentary procedures, it does provide some uniformity with regard to the factors which national parliaments will consider. The Commission has put in place an impact assessment system to prepare what should be an evidence-based process for political decision-making and to provide transparency on the benefits and costs of policy choices. ${ }^{32}$ A key element of this system is the Impact Assessment Board ${ }^{33}$ which provides independent quality control of the Commission's impact assessments. Since it was created in 2006 the Board has produced over 400 opinions, all of which are available to national parliaments to utilise in their own domestic scrutiny activiites. ${ }^{34}$ The purpose of impact assessments is that they should quantify benefits and costs when possible, but there are undoubtedly limits with regard to what can be precisely quantified within twenty-eight Member States. Inevitably, data is frequently limited, and the impact of EU legislation often depends on how national administrations implement it. This also means that aggregating figures for benefits and costs of EU legislation over time, as some stakeholders have requested, would not be a meaningful exercise. ${ }^{35}$

The evidence of the impact assessment process for the CESL is indicative of a much broader criticism that can be levelled at the Commission and its role in the policy-making and legislative process which operates to the detriment of national parliaments and to their fulfilling their role under Protocol 2. That is to say that the Commission is regularly failing to provide the necessary quantitative information within impact assessments in order for national parliaments to make a sufficiently informed judgement concerning the compatibility of a proposal with the principle of subsidiarity.

In relation to CESL a number of issues arose from the impact assessment that caused several national parliaments to question both the

\footnotetext{
32 See http://ec.europa.eu/governance/better_regulation/impact_en.htm.

33 See R Baldwin 'Is better regulation smarter regulation' (2005) 46 Public Law 485 who highlights that Impact Assessments are considered as the pivotal tool of better regulation by the Commission.

34 Available 5 April 2016 at: http://ec.europa.eu/governance/impact/ia carried_out/cia_2010_en.htm.

35 See C Radaelli 'Whither better regulation for the Lisbon Agenda' (2007) 14 Journal of European Public Policy 190 at 192-3.
} 
necessity and desirability of the proposal. ${ }^{36}$ For example, the EU Scrutiny Committee in the House of Commons ${ }^{37}$ was one of several national parliamentary chambers which highlighted the shortcomings of the Commission's impact assessment process and the limited quantitative and qualitative indicators and impact information which it provided which was ultimately used to justify legislative action under Article 114 TFEU. ${ }^{38}$ The EU Scrutiny Committee concluded that the incomplete and inaccurate impact assessment impeded effective subsidiarity monitoring and for this reason it delivered a Reasoned Opinion to the Commission. The EU Scrutiny Committee correctly highlighted that by virtue of Article 5 of Protocol 2, any draft legislative act should contain a 'detailed statement' making it possible to appraise its compliance with the principles of subsidiarity and proportionality. This detailed statement should, as a principle of best practice, include as a matter of course:

- some assessment of the proposal's financial impact;

- in the case of a Directive, some assessment of the proposal's implications for national and, where necessary, regional legislation; and

- qualitative and, wherever possible, quantitative substantiation of the reasons "for concluding that a Union objective can be better achieved at Union level'.

36 In addition to the House of Commons, Reasoned Opinions were received from the Austrian Federal Council, the Belgian Senate and the German Bundestag. The common feature of all these Reasoned Opinions was that the Commission had failed to establish a justification that the measure was necessary with all Reasoned Opinions highlighting that the optional nature of the measure undermined the Commission's argument of necessity.

37 See the Reasoned Opinion of the EU Scrutiny Committee of the House of Commons on Common European Sales Law, of 23 November 2011 at 1. Available 5 April 2016 at www.parliament.uk/business/committees/committees-az/commons-select/european-scrutiny-committee/scrutiny-reserve-overrides/.

38 The EU Scrutiny Committee in the House of Commons noted in its Reports that the consumer organisation Which? identified a Eurobarometer survey in which $80 \%$ of companies said they were never or not very often deterred by consumer contract law-related obstacles. $72 \%$ of companies said that the need to adapt and comply with different consumer protection rules in foreign contract laws has no impact or only a minimal impact on their decision to sell cross-border to consumers from other EU countries. Furthermore, 79\% of companies said that one single European consumer contract law would not change or only increase their cross-border operations a little. See HC 428-xlii Progress of Scrutiny (2010-12) Chapter 5. 
The detailed statement should also demonstrate an awareness of the need for any burden, whether financial or administrative, falling upon the EU, national governments, regional or local authorities, economic operators and citizens, to be minimised and to be commensurate with the objective to be achieved. Thus, the impact assessment must also address the principle of proportionality. The EU Scrutiny Committee, in line with other parliamentary chambers which drafted a Reasoned Opinion, concluded that neither the Commission's Explanatory Memorandum nor the impact assessment for the CESL satisfied the criterion and failed to include a 'detailed statement to make it possible to appraise compliance with the principle of subsidiarity' 39 (and proportionality), as required by Article 5 of Protocol 2. The Committee concluded that a failure to provide this information by the Commission constituted an infringement of an essential procedural requirement of Protocol 2. This judgement was based upon the limited justifications given by the Commission for the need for such legislation.

In its Explanatory Memorandum the Commission's impact assessment addressed subsidiarity in the following terms: ${ }^{40}$

This initiative complies with the principle of subsidiarity for a number of reasons. The objectives of facilitating the expansion of cross-border trade for business and purchases by consumers in the internal market cannot be fully achieved as long as businesses and consumers cannot use a uniform set of contract law rules for their cross-border transactions. The current legal framework is not sufficient, as it lacks a single set of uniform substantive rules which cover comprehensively the lifecycle of a cross-border contract. Furthermore, as market trends evolve and prompt MS to take action independently (e.g. in regulating digital content products) regulatory divergences grow. They lead to increased transaction costs and legal complexity for business, as well as uncertainty, affecting businesses and consumers involved in crossborder transactions.

A number of stakeholders acknowledge that the existence of differences in contract laws have led to legal fragmentation which can affect the functioning of the internal market; this may entail additional transaction costs and legal uncertainty for business and a lack of consumer confidence. The Union is best placed to address obstacles to the functioning of the internal market as these obstacles have a clear cross-border dimension. More specifically, it is best placed to address contract law related obstacles by developing a single set of uniform substantive contract law rules. It will add value to the existing legal

\footnotetext{
39 See HC 428-xlii Progress of Scrutiny (2010-12) at p. 1.

40 See COM(2011) 635 final Draft Regulation on a Common European Sales Law for the European Union at p. 9.
} 
framework by creating such rules for consumers and businesses that engage in cross-border transactions.

While the Commission provides a robust justification of the principles behind the CESL, resting much of the argument on the necessity of the CESL to improve the functioning of the internal market, it is questionable whether an impact assessment containing this form of generalist justification of market integration demonstrates conclusively that the EU legislation is either necessary, or that there is a clear added value to be gained. Moreover, such a justification, as provided in the case of the CESL, arguably fails to meet the Commission's own criteria for impact assessments which state that in order to improve impact assessments the Commission will conduct a 'more rigorous analysis of subsidiarity' 41 which includes, inter alia, 'more quantitative evidence and analysis' ${ }^{42}$ In particular, in the case of the CESL the EU Scrutiny Committee was most critical of the Commission for ignoring its own statistical evidence which indicated that there was no overwhelming necessity or added value to be gained from EU legislation. ${ }^{43}$

It is axiomatic that an optional sales law that is common to all Member States is something that can be better achieved at EU level than at national level. But that is to assume that the proposed CESL, or harmonisation of contract law more generally, is both necessary and that it will produce clear and identifiable benefits by reason of its scale and effect, compared with action by Member States. Both are requirements to be met for compliance with the principle of subsidiarity, but on the evidence available and with regard to the substance of the Regulation which makes the use of CESL optional, it is extremely doubtful that either requirement has been met.

41 See COM(2009) 15 final Third Strategic Review of Better Regulation in the European Union at p. 8.

$42 \operatorname{COM}(2009) 15$ at p. 8.

43 For example, the Commission's Consumer Market Scoreboard (March 2011) found the major reasons for a lack of cross-border trade to be practical. $62 \%$ of consumers cited fears of fraud, $59 \%$ were worried about what to do if problems arose and $49 \%$ were concerned about delivery and in the Commission's qualitative Eurobarometer survey on obstacles for citizens in the Internal Market (September 2011), the most prominent reason why consumers do not buy cross-border was that they prefer to buy locally. 


\section{THE INTERNAL MARKET IMPERATIVE AND REMOVING BARRIERS TO TRADE}

The overriding presumption within Article 5 TEU, which demonstrates that legislation conforms to the principle of subsidiarity, is that the EU cannot act if the objectives of the proposed action can be achieved sufficiently by the Member States. The fundamental question which is asked is whether it is necessary to operate and regulate at a higher level if the Member States themselves are not capable of implementing the pursued objectives closer to citizens. In most instances, the answer will inevitably be 'yes' because that is the fundamental requirement of legislative harmonisation. However, the harmonisation of different rules in the Member States with a legislative act cannot be identified as, nor should it be presumed to be, an objective of Article 5(3) TEU. If this were to be the case, the test of whether the Member States would not be capable of acting independently, would de facto be undermined. Furthermore, it would not be recognised that even with the operation of the principle of mutual recognition, barriers in the internal market caused by different rules in the Member States can still be overcome. This is certainly the case with regard to the proposed CESL where it is difficult to accept an argument of necessity for a common European sales law in circumstances where the Internal Market already functions in this regard, and where there already exists significant cross-border activity.

It has already been noted that Article 114 TFEU does not vest the EU legislator with 'a general power to regulate the Internal Market'. ${ }^{44}$ To that extent any measures based upon Article 114 TFEU should only be permitted where it will genuinely contribute to eliminating obstacles to trade and removing distortions of competition. ${ }^{45}$ In theory, this places a self-restraint upon the unlimited exercise of EU competence and jurisdiction and, in particular, prevents what is termed as 'competence creep' ${ }^{46}$ However, it is the recognition of the need for horizontal or flanking policies to support the Internal Market project, of which the CESL is one, as well as the desire by some Member States to harmonise rules relating to other policy areas such as social policy and the

44 Case C-376/98 Germany v European Parliament and Council (Tobacco Advertising) [2000] ECR I-8419 at para.83.

45 See for example the judgment in Case C-58/08 Vodafone Ltd and others $v$ Secretary of State for Business Enterprise and Regulatory Reform [2010] ECR I-4999.

46 See S Weatherill 'The constitutional competence of the EU to deliver social justice' (2006) 2 European Review of Contract Law 136-58. 
environment that have created tensions within the EU as to how far non-core Internal Market measures could also be the subject of harmonisation under Article 114 TFEU.

On the question of whether the legislative measure achieves the internal market objective of removing obstacles the Court will examine both its substance and effect. In case 436/03P Parliament $v$ Council the Court considered the question of the appropriate legal base for the introduction of the European Co-operative Regulation and detailed the necessary requirements in order to satisfy Article 114 TFEU. The Court highlighted that Article 114 TFEU empowers the legislature to adopt those measures which will be corrective and remove national distortions and genuinely have the object of improving the conditions for the establishment and functioning of the internal market. Substantively, the criterion to be satisfied requires that the measure contributes to the elimination of obstacles to the economic freedoms guaranteed by the Treaty. In the Tobacco Advertising judgment the Court stated: ${ }^{47}$

To construe that article as meaning that it vests in the Community legislature a general power to regulate the Internal Market would not only be contrary to the express wording of the provisions cited above but would also be incompatible with the principle embodied in Article [5 TEU] that the powers of the Community are limited to those specifically conferred on it.

Moreover, a measure adopted on the basis of Article [114 TFEU] of the Treaty must genuinely have as its object the improvement of the conditions for the establishment and functioning of the internal market. If a mere finding of disparities between national rules and of the abstract risk of obstacles to the exercise of fundamental freedoms or of distortions of competition liable to result therefrom were sufficient to justify the choice of [Article 114 TFEU] as a legal basis, judicial review of compliance with the proper legal basis might be rendered nugatory. The Court would then be prevented from discharging the function entrusted to it by Article [302 TFEU] of ensuring that the law is observed in the interpretation and application of the Treaty.

Article 114 TFEU may also be used as a legal base if the purpose of the legislative measure is to prevent the emergence of future obstacles to trade resulting from multifarious development of national laws, the emergence of such obstacles must be likely and the measure in question

47 Case C-376/98 Germany v European Parliament and Council (Tobacco Advertising) [2000] ECR I-8419 at paras 83 and 84 . 
must be designed to prevent them. ${ }^{48}$ It is though questionable whether the CESL will serve to remove such future obstacles to trade. Central to the Commission's justification for the CESL is what the Commission considers to be a barrier to trade that arises from the divergences in national laws. This diverse legislation, it is argued, places additional cost burdens upon traders to determine the precise scope and substance of contractual law within each jurisdiction in which they seek to operate. ${ }^{49}$ The Commission argues that by introducing an alternative, albeit non-compulsory, EU sales law which parties can choose to regulate their contractual relationship this will simultaneously stimulate trade by eliminating the barrier of multifarious contract laws and reduce cost burdens.

There is no doubt that the Commission's logic sounds appealing. It identifies the existence of a barrier and provides a simple solution based upon the creation of parallel uniform contract rules that parties may opt in to without any difficulty. Yet this analysis is rather simplistic and deceptive and fails to address some of the substantive questions raised by the CESL, which arguably create bigger barriers to the CESL being the preferred form of contract law for parties. The impact of diverging consumer contract law on business decisions in cross-border trading also seems to be exaggerated. According to the Commission's impact assessment ${ }^{50}$ only 7 per cent of companies perceive the 'need to adapt and comply with different consumer protection rules in foreign contract law' as having a large impact on their decision to sell across borders to consumers from other EU countries.

The CESL may also be criticised for its legal complexity which will by no means help to reduce barriers to trade. The fact that a wide range of matters, as set out in Recital (27), affecting the legal relationship between the parties are not addressed within the CESL regime is likely to undermine the intended aim of removing the need for businesses to incur transaction costs to obtain legal advice on another country's law. There is a legitimate concern that the proposals as drafted may add to confusion rather than reduce complexity. The exclusions in Recital (27) are as follows:

48 See, to that effect, Case C-350/92 Spain v Council [1995] ECR I-1985 at para.35; the tobacco advertising judgment at para.86, and Case C-377/98 Netherlands $v$ Parliament and Council [2001] ECR I-7079 at para.94.

49 See further COM(2011) 635 final, Proposal for a Common European Sales Law pp. 2-3.

50 See p. 13, footnote 55 . 
All the matters of a contractual or non-contractual nature that are not addressed in the Common European Sales Law are governed by the preexisting rules of the national law outside the Common European Sales Law that is applicable under Regulations (EC) No 593/2008 and (EC) No $864 / 2007$ or any other relevant conflict of law rule. These issues include legal personality, the invalidity of a contract arising from lack of capacity, illegality or immorality, the determination of the language of the contract, matters of non-discrimination, representation, plurality of debtors and creditors, change of parties including assignment, set-off and merger, property law including the transfer of ownership, intellectual property law and the law of torts. Furthermore, the issue of whether concurrent contractual and non-contractual liability claims can be pursued together falls outside the scope of the Common European Sales Law.

The substance of Recital (27) means that there are likely to be a number of legal gaps in the CESL which contracting parties will, if they choose to opt in to the CESL, have to be aware of. They will need to be clear with regard to which contractual issues fall outside the CESL and how they are to be resolved. As suggested above, it is unlikely that this will be possible without the assistance of legal advice which would seem to have a significant likelihood of increasing uncertainty and costs for traders, as well as potentially delaying the performance of the contract. This need to have a familiarity with existing national law makes a significant chink in the argument that the CESL creates a 'single uniform set of contractual rules' which eliminate the need for traders to investigate the contractual laws of other Member States.

A second issue to note on the issue of the internal market imperative is that for a legal code to be applied uniformly across the EU, and therefore break down barriers, it must be interpreted uniformly. There is, however, no mechanism for doing so in the CESL proposal. Article 14 requires Member States to notify final judgments of their courts which give an interpretation of the provisions of the CESL or any other provision of the Regulation. The Commission will set up a database of such judgments which presumably is intended to act as a central repository through which consistent application and interpretation may be monitored. A database of judgments will not, per se, set legal precedent for national courts, which are responsible for interpreting and enforcing the CESL. The absence of a single source of jurisprudence makes it likely that the CESL will be interpreted and applied differently across the Member States. This will add uncertainty rather than clarity to cross-border sales conducted under the new instrument, require legal expertise, and so undermine the essential purpose of the proposal. 
From a consumer protection perspective the CESL also fails to satisfy the test of necessity for the functioning of the internal market. The introduction of an 'optional' European contract law would increase legal uncertainty and is very likely to create confusion for consumers. ${ }^{51}$ Consumers will be faced with a situation in which different rules apply to the same products depending on whom they are purchasing them from and where the supplier is located. Under existing laws, consumers purchasing across EU borders can be confronted with different rules, but this is tempered by Article 6 of the Rome I Regulation which provides protection to consumers who will generally benefit from a higher level of protection available under their national law. Although the proposed CESL provides that both parties to the contract need to agree to its use, and that all consumers must be asked to give explicit consent, the reality is that consumer choice will be limited to accepting the contract offered by the supplier or not purchasing the product. By introducing a European body of law that businesses, in effect, can choose to be the choice of law, national consumer protection law similarly becomes 'optional' too.

Finally, though under Article 114(3) TFEU the Commission is obliged to ensure a high level of consumer protection when making internal market proposals, which includes the CESL, the effect and operation of the CESL as outlined suggest there must be considerable doubt with regard to whether the proposal will achieve this, and therefore whether action at the level of the EU rather than Member States will genuinely bring the greater benefits that the Commission claims. ${ }^{52}$

\section{CONCLUDING REMARKS}

The CESL provides a solution to a problem that does not really exist. Moreover, the proposal is not introduced under the correct legal base with Article 114 TFEU being an inappropriate mechanism through which to introduce a legislative measure which only provides optional contractual rules for parties. ${ }^{53}$ From a constitutional perspective it is perhaps the failure of the CESL Regulation to conform to the principle of subsidiarity

51 See further, Ganuza, and Gomez (2013) (n.18) at 32-4.

52 See the arguments of G Low 'Will firms consider a European optional instrument in contract law?' (2012) 33 European Journal of Law and Economics $521-40$.

53 See G Wagner 'The economics of harmonisation: The case of contract law' (2002) 29 Common Market Law Review 995-1023, highlighting that consumer ignorance will be a bar to harmonisation of EU contract law. 
which is of most concern. Monitoring compliance with the principle of subsidiarity is a key task for national parliaments and was highlighted as a significant development through which to secure improved legitimacy for EU legislative acts. Conformity with the principle of subsidiarity demonstrates both the legality and necessity of a legislative proposal within the integration process. The imprecise nature of the Commission's justifications and the evidence provided undermine this legitimacy and call into question the Commission's commitment to better regulation and delivering tangible benefits to EU citizens. The CESL is constitutionally unsound, does not improve consumer protection, nor will it be likely to significantly increase the volume of online trade, and, if the Commission believes that uniform contract rules are necessary then they should return to the drawing board.

Going forward the EU needs to create clearer priorities with respect to how it develops the internal market in order to secure improved consumer protection for citizens. While the CESL is not the answer, at least in its current form, there is a place for harmonised rules which offer citizens improved guarantees of security and protection when engaging in crossborder consumer contracts. In particular, the Commission could consider prioritising the modernisation of the legislation on enforcement which was considered as part of the review of Regulation 2006/2004 on consumer protection cooperation. ${ }^{54}$

The Review of Regulation 2006/2004 published in July 201455 acknowledges that better regulation of the digital economy should be a priority and highlights that improved common powers available to competent authorities would be a positive step forward. Such a step would be possible without the need for the CESL and would build upon existing cooperation between competent national authorities. Moreover, such a development would be less likely to trigger the constitutional objections that have accompanied the CESL proposal and offer the EU an opportunity to demonstrate that it is addressing genuine concerns of consumer protection and improving the functioning of the digital economy which remains a key EU strategy within the EU's sustainable growth agenda.

54 Regulation 2006/2004 of the European Parliament and Council of October 272004 on cooperation between national authorities responsible for the enforcement of consumer protection laws (OJ 2004 L364/1).

$55 \operatorname{COM}(2014) 439$ final. Report from the Commission on the functioning of the Regulation (EC) No 2006/2004 on cooperation between national authorities responsible for enforcement of consumer protection laws. 